\title{
EPHESIANS: AN ECCLESIOLOGY OF IDENTITY AND RESPONSIBILITY IN THE LIGHT OF GOD'S COSMIC PLAN AND A CANONICAL VIEW OF GOD'S PEOPLE.
}

GC Pereira

Baptist Theological College of Southern Africa

North-West University

\begin{abstract}
I show that God's programme in history is to create for Himself ${ }^{1}$ a people to have a relationship with them. Yahweh will be their God and they will be His people. In this way God's lordship becomes an experienced reality for creation. God's cosmic plan is to place all things under one head, even Christ. The activity of God creating a people continues in the church, now consisting of Jews and Gentiles. God's creation of His people is an ecclesiology of (substantialist) identity; they are what they have been created to be, and in Ephesians it is explicated by the fact that they are God's property, God's workmanship and God's dwelling. We are identified according to our vertical relationship. But the church also lives in horizontal relationships. Here I may speak about an ecclesiology of responsibility. To the community of believers our (relational) responsibility is to maintain unity and shalom. To society at large our (vocational) responsibility is to be an example of true community in unity and justice, and to share the gospel of Christ's ultimate lordship in accordance with God's cosmic plan. Thus, the question that pervades this whole discussion must be put succinctly, "How do God's people fit God's cosmic agenda by being indicatively and imperatively relevant?"
\end{abstract}

Key Words: Ephesians; Ecclesiology; God's People; Identity; Responsibility; God's Cosmic Plan

\section{Introduction}

The letter to the Ephesians has as its main theme the church of Jesus Christ. The letter is primarily ecclesiological in its content and intent. It is primarily an ecclesiastical document. Peter O'Brien ${ }^{2}$ concurs by saying that the letter presents a 'high ecclesiology' not in a localised sense, but in a distinctively universal way. Without going into the debate about the authorship of Ephesians, we believe that the Apostle Paul is providing us here

I wish to state my awareness of gender-exclusive language used by many authors and in the Bible. I certainly believe that God, ontologically, cannot be referred to in gender specific ways; and I understand that the biblical use of gender for God is based on its anthropomorphic and patriarchal framework. So, my gender use in reference to God does not reflect a belief that God is male, but my preference is to use the masculine for ease of grammar (language flow) in writing, other theological concerns, and because the biblical text so renders it.

2 O'Brien, Peter 1999. The Letter to the Ephesians. The Pillar New Testament Commentary, (ed.) DA Carson. Grand Rapids: WB Eerdmans, p. 25. 
tremendous insight into the make-up, purpose and responsibility of the church. An ecclesiology of identity and responsibility is necessary to define the church and its purpose within this world.

The church has a peculiar identity; and that identity is defined by its purpose and demonstrated in its responsibility. As the People of God the church is to live out what God has prescribed for it according to his cosmic plan. The church is to live out its purpose three-directionally; firstly toward God, then toward the believing community itself, and thirdly, toward those in the world who are outside Christ. Using Sands ${ }^{3}$ categories for the Imago Dei, I shall consider the church under its substantialist, relational and vocational attributes. As the 'People of God' we are to live in each of these directions, both in terms of our identity (substantially) on the one hand and in terms of our responsibility (relationally and vocationally) on the other. The church's responsibility is the expression of its identity. Victor Paul Furnish must be credited with raising this as the essence of Paul's view of 'the new life' in his book, Theology and Ethics in Paul (originally published in 1968, and reprinted in 2009 by John Knox Press). He stated, for instance, that, "God's will is that one should put his whole being at God's disposal. In his total 'belonging' to him he is to apply himself to what is good"4 (2009:189).

\section{The Identity of God's People}

The question of the identity of the church is more about who it is, than about what it does. When the church is considered as constituted of people, they need to know who they are in relation to God, and in relation to themselves and the world. In these relationships they are able to act in a way which characterises their identity. They are God's people; therefore they must live like God's people. Their identity thus defines their responsibility.

Ecclesiology must be subservient to the Word of God. The sovereign Lord is in control and history develops according to His wise plan. This plan has cosmic implications. God will bring all things under one head, even Christ (Eph.1:10). This cosmic plan is initiated in the establishment of the church as the people of God. Therefore, I need first to look at the concept 'People of God.'

\section{The People of God Canonically}

The central covenantal principle that permeates the biblical message is found in the relationship between God and His people. The essence of the principal covenant is encapsulated in the statement, "... and I will be their God, and they shall be my people...", and all its variant renderings. The earliest occurrence in the Bible following Eden is found in Genesis 17:7-8 when God made a covenant with Abraham, and the last is found in Revelation 21:3 when God is finally to be a presence with His people. The principle occurs over 35 times in the Bible; sometimes stating only the one part of the principle ("I will be their/your God") and implying the other ("they/you shall be my people") too, and viceversa. In most occurrences, however, both parts are mentioned together. Though not

Sands, Paul 2010. "The Imago Dei as Vocation" in Evangelical Quarterly - An International Review of Bible and Theology. Vol. 82:1 Great Britain: Paternoster Press, pp. 28-41. Sands does not quite focus on ecclesiology as we do in this article, but we find his headings useful for our discussion.

4 Furnish, VP 2009:189. Other scholars, like Behm (TDNT 4:958) and Jeremias (TDNT 1:365), have voiced like sentiments. 
mentioned explicitly in its general form, the principle is found also in Ephesians where believers are called "God's holy people" (Eph. 5:3 and 2:19); whom God has set aside for Himself. $^{5}$

Various reasons are given in Scripture for the establishment of the covenantal relationship between God and His people. Importantly, these people are presented to the world as a testimony of God's manifold wisdom (Eph. 3:10). Even though they are set in a hostile world, their destiny lays a claim of high moral principles on them as God's people. ${ }^{6}$ I continue to provide reasons under broad categories:

- Firstly, this covenantal relationship comes as a promise of blessing to God's people for both them and those outside to see God's sovereignty, goodness and glory (Gen. 17:7; Dt. 29:13; Jer. 13:11; Jer. 30:22; Jer. 31:33; Ezek. 36:28; Ezek. 37:23; Heb. 8:10).

- Secondly, it is also the reason for the divine act of redemption in history (Ex. 6:7; Lev. 22:33; Lev. 25:38; Num. 15:41). God acts savingly towards His people in order to make them His people.

- Thirdly, the covenantal relationship was given to define what life in the community was supposed to be like (Jer. 24:7; Ezek. 36:28; Zech. 8:8). They were to show themselves as a community of love and righteousness. Their holiness was the expression of the image of God in them (Lev. 11:45).

- Fourthly, the covenantal relationship shows God as One faithful to His people, and who expects faithfulness from them too (Jer. 7:23; Jer. 11:4; Jer. 31:1; Jer. 32:38; Ezek. 11:20; Ezek. 14:11; Ezek. 37:23; Zech. 8:8).

- Perhaps the most important theme relating to this principle covenant, lastly, is that of God's holy presence with His people (Ex. 29:45; Lev. 26:12; Jer. 30:22; Ezek. 37:27; 2 Co. 6:6; Rev. 21:3). It is as Moses said in Exod. 33:15-16 when he spoke to God, that the people are distinguished as God's people by His presence with them.

We find close correlation with these reasons in the letter to the Ephesians.

- Firstly, in Ephesians the church is understood as existing for God's glory (Eph. 1:19; 3:8-11). The enlightenment of all (Eph. 3:9) means that all people should see it. ${ }^{7}$ Paul heaps up adjectives (immeasurable and great) to describe the glorious power of God. ${ }^{8}$ God is glorified by the recognition of His power.

- Secondly, the redemptive acts of God are seen in the making of His people; particularly now in the redemption of the Gentiles, so that they who were not God's people, have become His people. They who were excluded from the commonwealth of Israel are now included in Christ (Eph. 2:11-16, 19-21; 3:6, 14-15). As Israel was the people of God, so now the church consists of Gentiles too. The Gentiles' inclusion is a blessing of grace. The glory of the grace of God is the reason for the revelation of the mystery of the church (Eph. 1:6; 2:11-16). Their redemption by the blood of the Cross is the means by which the church becomes the possession of God (Eph. 1:7, 14, 18; 4:30). I can

Snodgrass, Klyne 1996. Ephesians. The NIV Application Commentary, (ed.) Terry Muck. Grand Rapids:

Zondervan, p. 268.

Martin, Ralph 1991. Ephesians, Colossians, and Philemon. Atlanta: John Knox Press, p. 63.

Best, Ernest 2003. Ephesians. London: T\&T Clark Ltd., p. 148.

8 Faulkes, Francis 1989. Ephesians. Nottingham: Inter-Varsity Press, p. 70. 
understand Breytenbach's ${ }^{9}$ statement when he says, "Die Joodse moederkultuur, hoe belangrik dit ook vir die ontstaan en formulering van die evangelie is, word oorskry,",10 when he comments about the glory of God's grace.

- The next reason is replicated here. Their new life in Christ is the ethical basis upon which the church is to live faithfully and pleasingly before God (Eph. 4:1; 5:1-21;24-27).

- Our union with Christ is, in fact, the source of our good works. Fesko ${ }^{11}$ eloquently verbalises my sentiment when he says: "Union with Christ is the intimate, vital, and spiritual union between Christ and his people, in virtue of which he is the source of their life and strength, of their blessedness and salvation." Their gift of unity in the Spirit is to be maintained by a community living under the principles of peace (Eph. 4:3). Paul's exhortation is to walk (live) in a way that is consistent with being a Christian. ${ }^{12}$ We are expected to conduct ourselves according to our identity as the people of God.

- Finally, God's personal presence within the church is the greatest blessing of His people (Eph. 2:18,22; 3:12,17). God dwells among them and in them. The image of God is now seen in God's people as Christ is formed in the church (Eph. 1:12; 2:10; 3:19,20; 4:24; $5: 1)$. I agree with Sands ${ }^{13}$ when he says, "Human beings participate in the divine image only as they become disciples of Christ ... to the extent that their lives conform to Christ. The imago Dei is an eschatological reality ... a dynamic and communal reality rooted in redemption." The church has stepped into the place of Israel in the unbroken divine plan of salvation. ${ }^{14}$ They are the dwelling-place of God, also, because they have become members of God's household (Eph. 2:19).

These reasons for the existence of God's people demonstrate very much also the purpose for which they exist. Let us first consider the identity of the church.

\section{The Church's Identity (Substantially) as the People of God in Ephesians}

Who are God's people? The question about the church's identity must be bound inextricably to a Trinitarian concept of God because, similar to the God-head it is also a community, ${ }^{15}$ and because salvation is a Trinitarian expression. ${ }^{16}$ The unity in community of the church is understood predominantly by Paul's use of the body metaphor. We are many members in one body. Schreiner ${ }^{17}$ admits that as the body of Christ, Christ, not the church, has priority. He goes on to say that the unity of the body is realised at baptism into

\footnotetext{
9 Breytenbach, C 2010. "Eers die Jode, dan die Grieke: Paulus as Sendeling” in Scriptura Vol. 103, Stellenbosch: Stellenbosch University, p. 132.

10 A literal translation is: "The Jewish base-culture, however important it may be for the origin and formulation of the Gospel, is [here] exceeded."

11 Fesko, VK 2010. "Sanctification and Union with Christ: A Reformed Perspective" in Evangelical Quarterly An International Review of Bible and Theology, Vol. 83. 3. Great Britain: Paternoster Press, pp. 197-214.

12 Talbert, Charles. 2007. Ephesians and Colossians. Paideia Commentaries on the New Testament. Grand Rapids: Baker Academic, p. 108.

13 Sands, Paul 2010. “The Imago Dei as Vocation” in Evangelical Quarterly - An International Review of Bible and Theology. Vol. 82:1 Great Britain: Paternoster Press, pp. 28-41, p. 31.

14 Schnackenburg, R 1991. The Epistle to the Ephesians. Edinburgh: T\&T Clark Ltd., p. 120.

15 The Trinitarian community is here taken as a basic Evangelical presupposition. It is taken for granted.

16 Ephesians speaks for example of the Father predestining, the Son redeeming, and the Spirit sealing and empowering.

17 Schreiner, Thomas 2001. Paul: Apostle of God's Glory in Christ. Leicester: Apollos, p. 335.
} 

one body (1 Cor. 12:13). They have been baptised into Christ (Gal. 3:27). We are reminded by Green ${ }^{18}$ that the church's communal participation in the eschatological Spirit began on the Day of Pentecost. Therefore to be baptised into the body is to be baptised into Christ, initiated on the Day of Pentecost. I find support for such an assertion in the statement of 1 Corinthians 12:12, that the one body is identified with Christ. This identity has cosmic implications. Lincoln ${ }^{19}$ expresses that believers are related explicitly to the cosmic Christ in whom all things are summed up (Eph. 1:10). Komolafe ${ }^{20}$ articulates in agreement that "the epistle to the Ephesians offers such perspective, especially with its emphasis on cosmic reconciliation and unity in Christ."

Firstly, in relation to God, the identity of the Church in Ephesians is established substantially in the facts that it is God's property (Eph. 1:14), God's workmanship (Eph. 2:10) and God's dwelling (Eph. 2:22). I have selected these three facts because of their Trinitarian significance and because they support the relational and vocational functions of the church. In Ephesians the church's identity is founded in the triune God. Therefore this identity can only be gained as a redemption endowment. Sands ${ }^{21}$ makes a similar assertion, but in reference to the Imago Dei. Our identity is obtained by faith in Christ (Eph. 2:8-9). It is a gift. The substantial vertical connection as God's property, workmanship and dwelling, places God's people in a horizontal relational and vocational connection too. For now, we must consider only the substantial connection.

\section{God's Possession (Eph. 1:12-14)}

A communal understanding of our texts above cannot be avoided. They are "less about individual soteriology than about communal ecclesiology, and in particular, the new converts' place in the church of Jesus Christ." ${ }^{22}$ So, instead of a 'person' of God, we are rather to speak about the 'people' of God. The Church is God's property; all believers, Jews and Gentiles, are included. The Jewish forebears are the church's foundation, because the prophets, Christ and apostles were armed with the promises and the Law, and the first believers with the Gospel of the death and resurrection of Jesus Christ. This whole new community has become the possession of God through his act of redemption in Christ. That is why I see it as a divine redemption endowment.

The new community, which is God's possession, is multi-ethnic. Acosta ${ }^{23}$ reminds us that "the foundation on which the identity of the people of God rests is not ethnic or geographic or linguistic, but ... theological." It is not anthropological, but theological. It is

18 Green, Chris E 2011. "The Body of Christ, the Spirit of Communion: Re-Visioning Pentecostal Ecclesiology in Conversation with Robert Jenson" in Journal of Pentecostal Theology, Vol. 20:1. Netherlands: Koninklijke Brill NV, pp. 15-26.

19 Lincoln, Andrew 1990. Ephesians. Word Biblical Commentary. Dallas: Word Books Publishers, p. 35.

20 Komolafe, Sunday B 2007. "Christ, Church, and the Cosmos: a Missiological Reading of Paul's Epistle to the Ephesians" in Missiology - An International Review, Vol. 35:3. Wilmore: Willian R Burrows, pp. 273-286.

21 Sands, Paul 2010. "The Imago Dei as Vocation" in Evangelical Quarterly - An International Review of Bible and Theology. Vol. 82:1 Great Britain: Paternoster Press, pp. 28-41.

22 Haberer, Jack 2008. "Ephesians 1:15-23" in Interpretation - A Journal of Bible and Theology, Vol. 62 No. 8. USA: Sheridan Press, pp. 312-318.

23 Acosta, Milton 2010. "Ethnicity and the People of God" in Evangelical Review of Theology, Vol. 34:1. Great Britain: Paternoster Press, pp. 58-70. 
a divine endowment rather than a human construct. Allow us to change what Acosta ${ }^{24}$ says to be 'historical' in the statement, "Israel's priority with respect to the Gentiles is historical, not social or psychological", rather to 'salvation-historical'. By definition salvation-history is a God-ordained history for the purpose of the ultimate gathering of God's people. Nevertheless, the whole new community (the church), consisting of all nations and cultural backgrounds, is God's possession.

Now, I shall briefly consider Ephesians 1:14 (NIV); "who is a deposit guaranteeing our inheritance until the redemption of those who are God's possession - to the praise of His glory" (our emphasis). This is an interpretive translation of the Greek text $\varepsilon \varsigma \pi 0 \lambda v$ $\tau \rho \omega \sigma \mathrm{v} \tau \varsigma$ $\pi \varepsilon \rho ı \pi$ เท́ $\sigma \varepsilon \omega \varsigma$, literally translated as, "to the redemption of the possession". There is no debate about taking $\varepsilon \zeta$ in a temporal sense, so that 'until' is accepted universally. What is debated is the issue of 'possession'. Does it refer to the believers' promised blessing, or does it refer to God's possession? I agree with the NIV's translation, and Lincoln ${ }^{25}$ who supports the latter with a convincing argument:

Elsewhere in the NT $\pi 0 \lambda v i \tau \omega \sigma \mathrm{v} v$ is always an act of God. Here, too, he is the most likely agent of redemption and therefore also the subject of 'possession.' God's people as the object of his possession is a common OT theme (cf. Exod. 19:5; Deut. 14:2; 26:18; Mal $3: 17$ ) and is found elsewhere in the NT in Acts 20:28 and 1 Pet. 2:9... Here in 1:14 and in 4:30 redemption has future reference, while in 1:7 it was treated as a present possession of believers. In relation to the rest of the sentence, in this phrase $\varepsilon \varsigma$ should be seen as indicating the goal rather than as having a purely temporal sense. The Spirit functions as the guarantee of believers' inheritance, looking toward or vouching for God's full redemption of that for which he has made this down-payment. Final deliverance by God means his taking full and complete possession of those who have already become his.

Our identity as God's possession in relation to Christ and the Holy Spirit is exemplified in the statements that "you were included in Christ" (verse 13) and "you were marked in him (Christ) with a seal, the promised Holy Spirit" (verse 14). The possession of us is therefore a Trinitarian possession. Being God's possession it must be understood that we are holy even before we do holy deeds. Sanctification is spoken of as a completed work and present reality of those who are in Christ (Ac. 20:32; Ac. 26:18; 1 Co. 1:2; 1 Co. 6:11; 1T h. 5:23; Heb. 9:13; Heb. 10:29; 1 Pt. 1:2). Therefore I cannot agree with Fesko ${ }^{26}$ when he expresses his general belief that, in the ordo salutis (order of salvation), justification always precedes sanctification. I cannot say that that is the case in God's determination to sanctify the church. In fact it is futile to speak of an order or process when we refer to pre-determined and eternal categories. I now consider the church as God's workmanship.

\section{God's Workmanship (Eph. 2:6-10)}

The concept of God's workmanship is perhaps one of the clearest, most expressive and most loved descriptions of our relationship to God. Who we are and what we will become depends on how God is forming us. Again, this must be seen as a divine endowment and a

$24 \quad$ Ibid, p. 67.

25 Lincoln, Andrew 1990. Ephesians. Word Biblical Commentary. Dallas: Word Books Publishers, p. 41.

26 Fesko, VK 2010. "Sanctification and Union with Christ: A Reformed Perspective" in Evangelical QuarterlyAn International Review of Bible and Theology, Vol. 83. 3. Great Britain: Paternoster Press, pp. 197-214. 
gift of redemption. God's forming of us is uninfluenced by us; it is completely according to the good pleasure of His will in Christ. Praise goes to God alone for what He has done. Snodgrass $^{27}$ (1996:93-94) perceptively says that Eph. 2:8-10 has often been singled out as the most effective summary we have of the Pauline doctrine of salvation by grace through faith. The past, present, and future of God's salvation in Christ are all in view here.

The community is God's new creation. Salvation is God's new creation in Christ. We are the result of God's activity and have what God has given. The creation language is visible in 2:15 where the community is created and in 4:24 where the life of God is created in the new self. The salvation of believers is 'His workmanship.' The sanctification of us is God's workmanship. "Such a work of God is fundamentally miraculous and the product of the divine will." ${ }^{28}$ Even the good works we are to do are what God has created in advance for believers. Good works are not commanded but ordained. Schreiner ${ }^{29}$ continues: "They are the fruit of God's creative work and his [sic] workmanship." Snodgrass ${ }^{30}$ summarises his discussion saying, "In God's planning, choosing, and acting, the aim was not only to save, but also to mark out the way we should live."

'Workmanship' is translated from the Greek word $(\pi \circ i$ in $\mu)$ that should more appropriately be translated 'handiwork', connoting a masterpiece. The redemptive endowment in all of this cannot be denied; it is "not from yourselves, it is a gift of God" (2:8). There can therefore be no basis for pride or any measure of self-congratulation. Mitton ${ }^{31}$ (1973:97) reminds us, "Pride in the presence of God is a most objectionable sin."

Our identity as God's workmanship in relation to Jesus Christ is also clear from our present text. God's kindness in Christ Jesus was shown to us when he saved us. We are God's workmanship created in Christ. Jesus Christ is the sphere of God's creative work. Dunn $^{32}$ reminds us that the 'new creation' is not the 'new age' because the former starts with the cross (Gal. 6:14-15). The new creation is not possible without the crucifixion, as we participate in it (Gal. 2:20). The new age or 'the coming ages' on the other hand speaks "to the cosmic plan of God 'to bring all things in heaven and on earth together under one head, even Christ' (Eph. 1:10)." ${ }^{33}$ God's workmanship is therefore a new creation activity with an age to come as its aim.

The Holy Spirit is not mentioned directly in our present text, but He implicitly pervades the thinking of Paul here. The textual context clearly indicates the fact in the formerly-now motif in Ephesians 2:1-10. Snodgrass ${ }^{34}$ enumerates the opposites, "Living in transgressions and sins is set opposite living in good works prepared by God; and this world is set opposite the heavenly realms; and death opposite life; and the sinful nature opposite union

\footnotetext{
27 Snodgrass, Klyne 1996. Ephesians. The NIV Application Commentary, (ed.) Terry Muck. Grand Rapids: Zondervan, pp. 93-94.

28 Schreiner, Thomas 2001. Paul: Apostle of God's Glory in Christ. Leicester: Apollos, p. 247.

$29 \quad$ Ibid, p. 247.

30 Snodgrass, Klyne 1996. Ephesians. The NIV Application Commentary, (ed.) Terry Muck. Grand Rapids: Zondervan, p. 107.

31 Mitton, C Leslie 1973. Ephesians. The New Century Bible Commentary. Grand Rapids: WB Eerdmans, p. 97.

32 Dunn, JDG 1998. The Theology of Paul the Apostle. Edinburgh: T\&T Clark Ltd., p. 412.

33 Komolafe, Sunday B 2007. "Christ, Church, and the Cosmos: a Missiological Reading of Paul's Epistle to the Ephesians" in Missiology - An International Review, Vol. 35:3. Wilmore: Willian R Burrows, pp. 273-286.

34 Snodgrass, Klyne 1996. Ephesians. The NIV Application Commentary, (ed.) Terry Muck. Grand Rapids:

Zondervan, p. 93.
} 
with Christ; and wrath opposite mercy and salvation"; and the spirit at work in the sons of disobedience opposite the Spirit that gives access to the Father. This same Spirit is able to strengthen with power in the inner man so that we are able to do good works (Eph. 3:16). The workmanship of God is achieved through the means and agency of the Spirit, by which these changes come about in our lives.

God's Dwelling (Eph. 2:19-22)

God's people have always been distinguished by the fact of God's presence with them. This fact finds its roots in the Old Testament. The construction of the Tabernacle in Exodus was understood as the formalisation of Yahweh presence-ing Himself among his people. Three tribes were located on every side of the Tabernacle, so that God was located at the centre of their camp. At this present time the imagery is extended to the people of God now consisting of both Jews and Gentiles. The temple is now no longer confined to a physical location or structure but is the church (cf. Schreiner). ${ }^{35}$

Writing to the Gentiles at Ephesus, Paul says: "you are no longer foreigners and aliens, but fellow citizens with God's people." Again, you "are members of God's household." Those who are God's people and are in God's household are those who qualify to have God's presence. It is instructive for us to consider Meneses ${ }^{36}$ at this point: "New Testament churches were assemblies associated with place, not ethnicity, bringing together diverse people and requiring them to submit to Christ, as to the head of the household." The divine presence is for all who are in Christ, the chief cornerstone of the holy temple, whether they are Jewish or Gentile because they are the eschatological holy dwelling of God. They are now all equally God's people with an equal privilege of God's presence with them all. Such equality must be a divine initiative; it is a redemption endowment.

The place of God's presence is the community of God's people. We need to be reminded with Acosta ${ }^{37}$ that the identity of the people of God rests not on ethnic nor geographic nor linguistic, but on theological underpinnings. I am positing that theological underpinning is the presence of God. Not that we are now multi-ethnic or that we are no longer geographically bound as was Israel, but that the Holy God has descended to be present. The people are now able to participate in the triune God. Althouse ${ }^{38}$ is correct when he says that our fellowship with the present God must be the framework of the fellowship of the saints, for we all participate in the divine presence. The community of God must be regulated by His holy presence.

Althouse $^{39}$ (2009:231) continues by acknowledging that the community is the locale for the beginnings of the reign of God. The community is also the locale and source of God's blessings, not only to those in the community, but also through them to bring life and light to society. The community is the locale for experiencing the holiness and sanctifying

35 Schreiner, Thomas 2001. Paul: Apostle of God's Glory in Christ. Leicester: Apollos, p. 342.

36 Meneses, Eloise 2012. "Transnational Identities and the Church: Examining Contemporary Ethnicity and Place" in Mission Studies, Vol. 29. Netherlands: Koninklijke Brill NV, pp. 62-78.

37 Acosta, Milton 2010. "Ethnicity and the People of God" in Evangelical Review of Theology, Vol. 34:1. Great Britain: Paternoster Press, pp. 58-70.

38 Althouse, Peter 2009. "Towards a Pentecostal Ecclesiology: Participation in the Missional Life of the Triune God" in Journal of Pentecostal Theology, Vol. 18:2. Netherlands: Koninklijke Brill NV, pp. 230-245.

39 Althouse, Peter 2009. "Towards a Pentecostal Ecclesiology: Participation in the Missional Life of the Triune God" in Journal of Pentecostal Theology, Vol. 18:2. Netherlands: Koninklijke Brill NV, pp. 230-245. 
benefits of God's person, for where God is, that place is holy. The community is also the locale of true worship. Ralph Martin ${ }^{40}$ contends that "the church is invested with a sacred aura as the dwelling place that God desires to inhabit."

We are able to clearly see the Trinitarian significance in our present text. According to Thomas Schreiner ${ }^{41}$ the Jerusalem temple pointed to and anticipated the church of Jesus Christ, which fulfils what the former temple envisioned. The Lord Jesus Christ is the cornerstone; that which keeps together the whole structure. In him all believers are being built together. Therefore, without Christ there can be no building; which means there can be no church and no Presence. The Holy Spirit indwells the Holiest Place (Gk. Naós) of the temple. The church is God's temple. The church is a community in which the Holy Spirit dwells. God finds his habitation in his new creation, the church. Christ and the Spirit dwell in our heart and inner man (Eph. 3:16-17).

Now that I have established our identity as it is depicted in Paul's letter to the Ephesians, we need to respond to the Trinitarian God accordingly. We must respond in gratitude for all the blessings given us (1:3-10). We must show the "praise of his glory" (1:12-14). We must seek to know God better and the benefits of our faith in him (1:17f). We must appreciate God's glorious grace in worshipful response (2:7). We may now approach God with confidence, even in the midst of suffering (3:12-13). We are to live a life worthy of our calling (4:1-3), putting off the old life for the new in Christ (4:22-24). We are to be imitators of God (5:1) and to put on the armour of God (6:10-18). I now turn to the ecclesiological responsibility.

\section{The Responsibility of God's People}

A particular identity requires a correlating responsibility. We must therefore live in a way that gives consideration to what we are. We are God's people; so our responsibility is to live in that way. We are God's property; so our responsibility is to act in a way complementary to that fact. We are God's workmanship; so we must reflect on the meaning of it. We are God's dwelling; so we must demonstrate the truth of that fact. Living out the fact of our identity must have relevance in our social contexts. Komolafe ${ }^{42}$ makes this same point about Ephesians when he speaks of an ecclesiology of responsibility: "That is, an ecclesiology that does not pay tribute to the letter as belonging only to ancient times, but that recognises it imposes an obligation relevant for being the church of Christ in the world today."

An ecclesiology of responsibility is expressed in the areas of relationship and vocation. While both of these areas may be explored in our three-directional way, I shall focus the relational on the community of believers and the vocational on society outside Christ; and then only as it explicates our identity as it is explored above. The first responsibility is towards God - through our continual sanctification. And then, the summary of the church's responsibility must be found in the cosmic plan of God "to bring all things in heaven and on earth together under one head, even Christ" (Eph. 1:10). Because the Lord of the church

40

41

42

Martin, Ralph 1991. Ephesians, Colossians, and Philemon. Atlanta: John Knox Press, p. 39.

Schreiner, Thomas 2001. Paul: Apostle of God's Glory in Christ. Leicester: Apollos, p. 343.

Komolafe, Sunday B 2007. "Christ, Church, and the Cosmos: a Missiological Reading of Paul's Epistle to the Ephesians" in Missiology - An International Review, Vol. 35:3. Wilmore: Willian R Burrows, pp. 273-286. 
is also cosmic Lord, we are compelled to see the connection between ecclesiology and cosmology (cf. Ryken et al.). ${ }^{43}$

\section{The Church and the Community (Relational) of Christ in Ephesians}

Our identity is first defined as it is related to God. Now, our responsibility to God must translate into our relationship and vocation to the church and society respectively; according to the overarching purpose of God's cosmic plan. What was a cosmic mystery has been revealed in the church and through the church for the purpose of Christ's lordship.

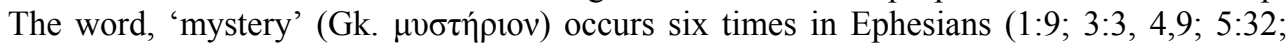
$6: 19)$. A mystery is known only by divine revelation. It is the revelation of the wise plan of God. In Ephesians this wise plan is primarily the inclusion of the Gentiles in Christ as God's people. "Both Jews and Gentiles constitute the 'one new humanity' in Christ with equal access to the Father". ${ }^{4}$

A major responsibility is that of maintaining unity. We are to make every effort to maintain the unity that was created by the reconciling death of Christ and the Holy Spirit by keeping the principles of shalom (Eph. 4:3). 'Shalom' is the Hebrew word for 'peace'. Lincoln ${ }^{45}$ comments concerning the unity of the community; it is to be maintained by employing the appropriate attitudes (humility, gentleness and patience) and ethics (love, egalitarianism and purity). These spell out the principles of shalom for us. $\operatorname{Kim}^{46}$ (2013:29) admits in this regard, "Christ's body also has to do with a way of living for believers." We must maintain the unity of the Spirit.

Our present quest for unity is faced with the issues of multi-culturalism and of multiethnicity. Some individual migrants have even adopted two or more cultures simultaneously, and we need to accommodate such diversity in the church. Paul, who himself was a product of different cultures, is an example (cf. Wessels \& Van Rensburg). ${ }^{47}$ He was a Christian who was a Hebrew (nationality), and who grew up in a Greek context (Tarsus), and was a privileged Roman citizen. More than ever before are we now challenged to accept the church's identity of 'Jew and Gentile' in one body. The newness of this new community demands that we incarnate our unity in diversity. Meneses ${ }^{48}$ intimates, "What is needed is a model of the church that acknowledges the value of ethnic affiliations ... and yet retains its focus on the person of Christ, in whom there is neither Jew nor Greek" (Gal. $3: 22$ ). The concern of every community should be to be ethnically and culturally inclusive. In fact it is to be more inclusive than that. Yong ${ }^{49}$ makes a case to include the 'weak',

43 Ryken, L, Wilhoit, J; Longman III, T 1998. Dictionary of Biblical Imagery. Downer's Grove: Inter-Varsity Press.

44 Komolafe, Sunday B 2007. "Christ, Church, and the Cosmos: A Missiological Reading of Paul's Epistle to the Ephesians" in Missiology - An International Review, Vol. 35:3. Wilmore: Willian R. Burrows, pp. 273-286.

Lincoln, Andrew 1990. Ephesians. Word Biblical Commentary. Dallas: Word Books Publishers, p. 236-237.

Kim, Yung Suk 2013. "Reclaiming Christ's Body (soma christou): Embodiment of God's Gospel in Paul's Letters" in Interpretation - A Journal of Bible and Theology, Vol. 67:1. USA: Sheridan Press, pp. 20-29.

47 Wessels, JM \& Van Rensburg, Fika 2010. "Paul, the Man of Three Worlds: Still Inspiring the Church Across Frontiers. In Scriptura Vol. 103. Stellenbosch: Stellenbosch University, pp. 189-199.

48 Meneses, Eloise 2012. "Transnational Identities and the Church: Examining Contemporary Ethnicity and Place" in Mission Studies, Vol. 29. Netherlands: Koninklijke Brill NV, pp. 62-78.

49 Yong, Amos 2013. The Bible, Disability, and the Church: A New Vision of the People of God. Grand Rapids: WB Eerdmans, p. 68. 
which for him includes the disabled bodies. The doctrine of the trinity demands a relational and egalitarian community.

Leaders in the church must therefore have a non-judgmental posture marked by humility, curiosity and openness to people. They need to encourage their people to be welcoming of all, and especially those who are different and are in Christ. Ekblad ${ }^{50}$ concludes that "reading Scripture for Good News that crosses barriers of race/ethnicity, social class, and culture requires awareness and great sensitivity to other people, the details of the biblical text, the Holy Spirit, and one's own place in the mix." The simplicity of Reagan's ${ }^{51}$ words is profound: "When the focus is upon difference, the result is exclusion, division, opposition and oppression". Leaders must embrace a divinely-given vision of egalitarian friendship and ministry that communicates these with an attitude of uniting and serving love. Yong ${ }^{52}$ reminds us that "in doing so, it will shape our self-understanding and will impact our practice."

\section{The Church's Responsibility (Vocational) to the World in Ephesians}

The church is the entity where God's presence is acknowledged and realised, and the first responsibility of the church to society is to show that glorious presence among them. If the presence of God encourages holiness in the community, such holiness can serve as a godly example to the world. The church must be a model community because it operates under the principles of shalom in attitude and ethics. I can put this in another way, using Garrett's ${ }^{53}$ idea; that "aesthetics and ethics must become their lens of eternity" into the cosmic plan of God. The loving egalitarian principles of God's community must become an inspiration to the world for them to emulate in their democratic participation and in their rejection of injustice. In their egalitarian quest, the church must be bold enough to encourage justice and to condemn injustice in society. I should propose to them "a theology of democracy" ${ }^{54}$ according to the principles applied in the household of God.

We must align ourselves with God's cosmic agenda in Christ; that all things are to be brought under Christ's lordship (Eph. 1:10). Meneses ${ }^{55}$ verbalises our sentiment in this regard, "But those that recognise the centrality of the gospel succeed due to the adoption of a central authority, Christ himself, who relativises all ethnic and national identities in favour of a common purpose, the spread of the gospel to others who have not heard it." The gospel is the power of God to salvation and to create a people for Himself out of those who were not a people.

50 Ekblad, Bob 2011. "Reading Scripture for Good News that Crosses Barriers of Race/Ethnicity, Class, and Culture" in Interpretation - A Journal of Bible and Theology, Vol. 65:3. USA: Sheridan Press, pp. 229-248.

51 Reagan, Debra A 2013. "Reclaiming the Body of Faith" in Interpretation - A Journal of Bible and Theology, Vol. 67:1. USA: Sheridan Press, pp. 42-57.

52 Yong, Amos 2012 "What's Love Got to Do with it? The Sociology of Godly Love and the Renewal of Modern Pentecostalism" in Journal of Pentecostal Theology, Vol. 24:1. Netherlands: Koninklijke Brill NV, pp. 113-134.

53 Garrett, Stephen M 2011. "Beauty as the Point of Connection between Theology and Ethics" in European Journal of Theology, Vol. 20:1. Great Britain: Paternoster Press, p. 151.

54 Kumalo, Simanga 2009. “'The People Shall Govern.' The Role of the Church in the Development of Participatory Democracy in South Africa" in Scriptura, Vol. 101. Stellenbosch: Stellenbosch University, pp. 246-258.

$55 \quad$ Meneses, Eloise 2012. "Transnational Identities and the Church: Examining Contemporary Ethnicity and Place” in Mission Studies, Vol. 29. Netherlands: Koninklijke Brill NV, pp. 62-78. 


\section{Conclusion}

Ephesians has demonstrated that it is largely ecclesiological in its message. Yet, its ecclesiology is subsumed in a Christology of cosmic headship. All things will be placed under Christ's authority, and God's wise plan will culminate in His glory. God's plan is revealed in the church; the church which before was a mystery. An ecclesiology of identity is bound up in God; we are the people of God. We are God's property. We are God's workmanship. We are God's dwelling. Who we are must be translated into the way we live; we are before we do.

An ecclesiology of identity is incomplete without an ecclesiology of responsibility. We have a three-directional responsibility; God-ward, community-ward and society-ward. Godward our responsibility is to worship and obey. Community-ward, our responsibility is to maintain unity and to adhere to the principles of shalom. Society-ward, the church must be an example of true community through its display of unity, egalitarianism and shalom, for society to emulate in their democratic participation and in their rejection of injustice. In this way we will have gained the right to share the gospel with them, and so invite them also to become fellow citizens of the household of God. 